\section{Replacing ultra-processed foods with fresh foods to meet the dietary recomendations: a matter of cost?}

\author{
Substituir alimentos ultraprocessados por alimentos \\ frescos para atender as recomendações \\ alimentares: uma questão de custo?
}

\section{¿Reemplazar comidas ultraprocesadas por comida fresca para cumplir con las recomendaciones dietéticas: una cuestión de coste?}

Emanuella Gomes Maia 1,2

Camila Mendes dos Passos 2,3

Fernanda Serra Granado 2

Renata Bertazzi Levy 4

Rafael Moreira Claro 2

\begin{abstract}
The study aimed to analyze the economic impact of the adoption of optimized and nutritionally balanced diets to Brazilian families, considering the Brazilian dietary guidelines and the economic disparities of the population. Data from the Brazilian Household Budget Survey from 2008-2009 (550 strata; 55,970 households) were used. About 1,700 foods and beverages purchased by the Brazilians were classified into 4 groups according to NOVA system. Linear programming models estimated isoenergetic diets preserving the current diet as baseline and optimizing healthier diets gradually based on the "golden rule" of the Brazilian dietary guidelines, respecting nutritional restrictions for macronutrients and micronutrients (based on international recommendations) and food acceptance limits (10th and 90th percentiles of the per capita calorie distribution from the population). The diet cost was defined based on the sum of the average cost of each food group, both in the current and optimized diets (BRL per 2,000Kcal/person/day). The economic impact of the Brazilian dietary guidelines to Brazilian household budget was analyzed by comparison the cost of the optimized diets to the cost of the current diet, calculated for the total population and by income level. Three healthier diets were optimized. Current diet cost was BRL 3.37, differed among low-and high-income strata (BRL 2.62 and BRL 4.17, respectively). Regardless of income, diet cost decreased when approaching the guidelines. However, low-income strata compromised their household budget more than two times the high-income strata (20.2\% and $7.96 \%$, respectively). Thus, the adoption of healthier eating practices can be performed with the same or lower budget.
\end{abstract}

Eating; Costs and Cost Analysis; Linear Programming
Correspondence

E. G. Maia

Universidade Estadual de Santa Cruz.

Campus Soane Nazaré de Andrade, Rod. Ilhéus-Itabuna

Salobrinho Km 16, Ilhéus, BA 45662900, Brasil.

manugmaia@hotmail.com

1 Universidade Estadual de Santa Cruz, Ilhéus, Brasil.

2 Universidade Federal de Minas Gerais, Belo Horizonte, Brasil.

3 Universidade Federal de Viçosa, Viçosa, Brasil.

4 Universidade de São Paulo, São Paulo, Brasil. 


\section{Introduction}

The non-communicable diseases (NCD) are the leading causes of death worldwide; however, their greatest burden can be seen among low- and middle-income countries. In 2016, NCD were responsible for $78 \%$ of deaths in these countries, resulting in major burden not only to population's health and quality of life, but also to workforce productivity and country's economic prosperity 1 . Thus, efforts must be focused on reducing the prevalence of major risk factors for NCD, with special focus on unhealthy food consumption 2,3 .

In this sense, food-based dietary guidelines offer a unique opportunity to benefit population health. According to the Food and Agriculture Organization of the United Nations (FAO) 4, these guidelines provide context-specific advice and principles on healthy diets and lifestyles to establish a basis for public food and nutrition policies, promote healthy eating and prevent diseases. Brazil has an innovative and a worldwide-recognized dietary guideline 5 , based on the NOVA food classification system 6 . This system has been used in several countries not only to effectively address the quality of diets and their effect on all forms of malnutrition, but also on the sustainability of food systems ${ }^{6}$. The consumption of fresh food (unprocessed or minimally processed foods) is enforced as the basis of food consumption, whereas the consumption of ultra-processed foods is discouraged 6 .

Appropriate knowledge about the relation between diet and health is not enough for the adoption of a healthy diet. Economic factors have also been emphasized as a primary determinant of food choices 7 . A robust set of evidences from high-income countries indicates that fresh foods with low energy density and high nutritional value (such as fresh meat, fruits and vegetables) cost more by calories than lower-quality ultra-processed foods 8,9 , suggesting that healthy diets could be unaffordable for an expressive share of the population. In Brazil, the price variation between foods classified as unprocessed or minimally processed is high, ranging from cheapest foods such as rice, beans, roots and tubers, to more expensive foods such as vegetables, fish, meats and fruits 10 . Thus, the diet cost to meet the Brazilian dietary guidelines recommendations is still uncertain.

Diet cost can only be partially understood by the comparison between the prices of different food groups, which requires more complex studies for an accurate conclusion, using techniques such as the linear programming mathematical method. This method can be used to optimize a function (healthy diets, for example) from a set of constraints (such as nutritional recommendations of the country). This approach was already used to develop cost-minimized nutritionally adequate food baskets both in studies among high-income countries 9,11 and in studies among middle- and low-income countries 12,13. However, these studies tend to focus exclusively on the nutritional profile of the diet to define healthy eating. Thus, the objective of our study was to analyze the economic impact of the adoption of optimized and nutritionally balanced diets on Brazilian household budget, considering the recommendations of the Brazilian dietary guidelines and the economic disparities of the population.

\section{Methods}

\section{Study design, sampling and data collection}

We performed an ecological study based on data from the last Brazilian Household Budget Survey (POF 2008-2009) conducted by the Brazilian Institute of Geography and Statistics (IBGE).

The POF 2008-2009 used a complex clustered sampling procedure in two-stages with the random selection of census tracts in the first stage and of households in the second stage, resulting in a representative sample of households in the country. Initially, the 12,800 census tracts of the country (from the 2000 Demographic Census) were organized into strata with high geographic and socioeconomic homogeneity. Census tracts were then randomly selected from each stratum, proportionally to the number of households in the stratum. Households from each tract were selected by simple random selection without replacement. The selected census tracts and their households were distributed uniformly throughout the four quarters of the year of data collection to cover all seasonal variations in expenditures and family income in each stratum. The final sample was composed of 550 strata, 
involving 4,696 census tracts and 55,970 households. A detailed description of the sampling process is available on IBGE 14.

The data collection of POF 2008-2009 was conducted from May 2008 to May 2009 through seven questionnaires in each selected household. Information of food and beverage purchased for household consumption and family income were the main information from the POF 2008-2009 used in our study. All foods and beverages purchased for household consumption were registered in an electronic booklet by the head of the household for seven consecutive days (supported by a trained interviewer, if necessary). Detailed information was registered for each purchase, such as the name of the product, the amount acquired (in shopping units and in grams or milliliters) and the total value expended. Data from 1,700 foods and beverages were available. Once POF 2008-2009 were collected over a year, IBGE deflated expenditure values to a reference date in the middle of the data collection period (January 15,2009 ) 14 . More details on the deflation process used by IBGE can be obtained from the system report 14 .

The short reference period (7 consecutive days) used in the POF 2008-2009 to record food expenditures does not allow the identification of the usual food purchase patterns of each household studied. Thus, the 550 household strata were defined as units of analysis. These units of analysis allowed the identification of the annual food purchase pattern with great precision, without compromising the geographic and socioeconomic variation in the data 15 .

\section{Data organization and classification of foods}

Initially, the records of each food item purchased by the families of the same stratum were added. When appropriate, the inedible fraction of foods was excluded using the corresponding correction factors 16 . The total amount of each food was converted into energy (Kcal), using the Brazilian Food Composition Table (TACO) 17 or, in a complementary way, the official food composition table for the United States 18. The total energy amount (Kcal) purchased and the costs were divided by seven and by the number of individuals in the stratum to express daily per capita consumption and a proportional expenditure value. Monthly per capita income, expressed in Reais (BRL), was estimated by dividing the sum of the income of all households in the stratum by the total number of individuals in the stratum.

Foods were classified into 4 groups and 35 subgroups according to NOVA food classification system used in the Brazilian dietary guidelines 6: (i) unprocessed or minimally processed foods (13 subgroups: rice; bean; pasta; wheat flour; cassava flour; fruits; vegetables; roots and tubers; milk and plain yoghurt; poultry and fish; beef and pork; eggs; other unprocessed or minimally processed foods), (ii) processed culinary ingredients (6 subgroups: sugar; salt; spice; plant oils; animal fats; other processed culinary ingredients), (iii) processed foods (4 subgroups: fresh bread; processed cheeses; processed meats; processed vegetables), and (iv) ultra-processed foods (12 subgroups: industrial bread; cookies, cakes and pastries; ice creams, chocolates and other candies; crackers and salty snacks; soft drinks; other non-alcoholic sweetened beverages; ultra-processed meats and sausages; ready meals and industrial blends; sauces and broths; breakfast cereals; margarine; ultra-processed cheeses).

\section{Model of optimization by linear programming and data analysis}

All foods and beverages were grouped in the 35 aforementioned subgroups, distributed in the four major food groups. Current diet was defined based on the average per capita amount of each subgroup (adjusted to represent a 2,000Kcal diet). Subsequently, the average contribution of each food group on total calories was estimated to represent the current diet. The current diet was preserved as baseline and optimized diets presented gradually increasing limits to increasingly meet the Brazilian dietary guidelines towards a healthy eating.

The model of optimization by linear programming is defined by three features: the goal function, the decision variables and the list of linear constraints 13 . Briefly, a goal function was defined to summarize the distance between the nutritional composition of the optimized diets and the current diet

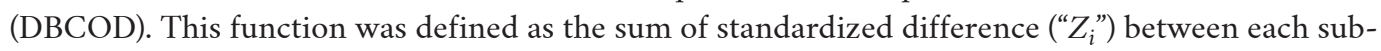
group portion size selected by linear programing (" $X_{i}^{\prime}$ ) (with $i=1$ to $\mathrm{n}$, in which $\mathrm{n}$ is equal to the total 
number food subgroups in the analysis) and the mean portion sizes (" $M_{i}$ ") observed in the Brazilian population for the related subgroup, divided by $M_{i}$. However, for our analysis, the total difference cannot be estimated simply by adding absolute values of difference for each subgroup, since this would lead to a nonlinear function 19 . Thus, a constraint must be imposed to $Z_{i}$ to always ensure a positive value for each standardized difference, as follows:

$$
\mathrm{DBCOD}=\mathrm{Z}_{1}+\mathrm{Z}_{2}+\ldots+\mathrm{Z}_{\mathrm{n}}
$$

$Z_{i}$ is equivalent to positive value for each:

$$
\begin{gathered}
\mathrm{Z}_{1} \geq\left(\mathrm{M}_{1}-\mathrm{X}_{1}\right) / \mathrm{M}_{1} \text { and } \mathrm{Z}_{1} \geq-\left(\mathrm{M}_{1}-\mathrm{X}_{1}\right) / \mathrm{M}_{1} \\
\mathrm{Z}_{2} \geq\left(\mathrm{M}_{2}-\mathrm{X}_{2}\right) / \mathrm{M}_{2} \text { and } \mathrm{Z}_{2} \geq-\left(\mathrm{M}_{2}-\mathrm{X}_{2}\right) / \mathrm{M}_{2} \ldots \\
\mathrm{Z}_{\mathrm{n}} \geq\left(\mathrm{M}_{\mathrm{n}}-\mathrm{X}_{\mathrm{n}}\right) / \mathrm{M}_{\mathrm{n}} \text { and } \mathrm{Z}_{\mathrm{n}} \geq-\left(\mathrm{M}_{\mathrm{n}}-\mathrm{X}_{\mathrm{n}}\right) / \mathrm{M}_{\mathrm{n}}
\end{gathered}
$$

The decision variables were the relative contribution (\%) of the four food groups from NOVA system. The linear constrains were: (i) nutritional restrictions for macronutrients (carbohydrates, free sugars, protein, total and saturated fat and total fiber) and micronutrients (sodium, calcium, iron, vitamins $\mathrm{C}$ and $\mathrm{A}$, and potassium), based on international recommendations from the World Health Organization (WHO) and the U.S. Institute of Medicine, and (ii) acceptability constrains, limited to the 10th and 90th percentiles of the per capita calorie distribution in the strata to prevent the models from resulting in non-acceptable diets (adjusted to represent a 2,000Kcal diet).

Detailed information about the decision variables and the linear constraints used in the models of optimization by linear programming is available in Tables 1 and 2.

The decision variables of linear programming were defined based on the "golden rule" of the Brazilian dietary guidelines: "Always prefer natural or minimally processed foods and freshly made dishes and meals to ultra-processed foods" 20 (p. 47). Thus, quintiles of participation of unprocessed and minimally processed foods and of ultra-processed foods on total calories were estimated to provide acceptable limits for the optimized diets (isoenergetic diets - 2,000Kcal). Briefly, the optimization of healthier diets comprised, at the same time, the following conditions: (i) gradual increase of unprocessed or minimally processed foods (until it exceeded the average acquisition of this food group in its fifth quintile of the relative contribution - largest acquisition), (ii) decrease of processed culinary ingredients and processed foods (relative contribution of these groups were equal or less than the current diet), and (iii) gradual decrease of ultra-processed foods (until it exceeded the average acquisition of this food group in its first quintile of the relative contribution - lowest acquisition).

The diet cost was defined based on the sum of the average cost of each food group, both in the current and optimized diets (BRL per 2,000kcal/person/day). Thus, the economic impact of the Brazilian dietary guidelines on the Brazilian household budget was analyzed by comparing the cost of the optimized diets with the cost of the current diet, estimated for the total population and according to economic level of the families (tertiles). Additionally, the food budget share was also estimated considering the economic level of the total population (BRL 887.6), of the low-income strata (strata from the first tertile of per capita income distribution, BRL 389.8) and of the high-income strata (strata from the third tertile of per capita income distribution, BRL 1,570.6). Daily food expenditures were multiplied by 30 to reflect the entire month.

Linear programming models were executed in the function Solver of the Microsoft Office Excel 2010 (https://products.office.com/). The Stata statistical software, version 14.2 (https://www.stata. com), was used in the organization and analysis of the data, allowing the use of weighting factors and all aspects of the complex sampling of the dataset. 
Table 1

Relative contribution (\%) of food groups to total energy availability. macro- and micronutrient constraints in the three optimized diets * by linear programming models. for the total population and for levels of income. Brazil. 2008-2009.

\begin{tabular}{|c|c|c|c|c|c|c|c|c|c|c|c|c|}
\hline \multirow[t]{4}{*}{ Variables } & \multirow{2}{*}{\multicolumn{4}{|c|}{ Total }} & \multicolumn{8}{|c|}{ Tertiles of per capita income distribution } \\
\hline & & & & & \multirow{2}{*}{\multicolumn{4}{|c|}{$\begin{array}{l}\text { 1st ** } \\
\text { Optimized diets }\end{array}$}} & \multirow{2}{*}{\multicolumn{4}{|c|}{$\begin{array}{l}\text { 3rd } * * * \\
\text { Optimized diets }\end{array}$}} \\
\hline & \multirow{2}{*}{$\begin{array}{l}\text { Cur- } \\
\text { rent } \\
\text { diet }\end{array}$} & \multicolumn{3}{|c|}{ Optimized diets } & & & & & & & & \\
\hline & & 1 & 2 & 3 & $\begin{array}{l}\text { rent } \\
\text { diet }\end{array}$ & 1 & 2 & 3 & $\begin{array}{l}\text { rent } \\
\text { diet }\end{array}$ & 1 & 2 & 3 \\
\hline \multicolumn{13}{|l|}{$\begin{array}{l}\text { Relative } \\
\text { contribution (\%) of } \\
\text { food groups to total } \\
\text { energy availability }\end{array}$} \\
\hline $\begin{array}{l}\text { Unprocessed } \\
\text { or minimally } \\
\text { processed foods }\end{array}$ & 48.9 & 48.9-54.9 & $54.9-60.8$ & $\geq 60.8 \#$ & 55.3 & $55.3-61.5$ & $61.5-67.7$ & $\geq 67.7 \#$ & 43.4 & $43.4-46.8$ & $46.8-50.2$ & $\geq 50.2 \#$ \\
\hline $\begin{array}{l}\text { Processed } \\
\text { culinary } \\
\text { ingredients }\end{array}$ & 24.3 & $\leq 24.3$ & $\leq 24.3$ & $\leq 24.3$ & 25.4 & $\leq 25.4$ & $\leq 25.4$ & $\leq 25.4$ & 22.8 & $\leq 22.8$ & $\leq 22.8$ & $\leq 22.8$ \\
\hline Processed foods & 8.9 & $\leq 8.9$ & $\leq 8.9$ & $\leq 8.9$ & 7.5 & $\leq 7.5$ & $\leq 7.5$ & $\leq 7.5$ & 9.5 & $\leq 9.5$ & $\leq 9.5$ & $\leq 9.5$ \\
\hline $\begin{array}{l}\text { Ultra-processed } \\
\text { foods }\end{array}$ & 17.8 & 17.8-13.5 & $13.5-9.1$ & $\leq 9.1 \# \#$ & 11.8 & 11.8-9.0 & $9.0-6.2$ & $\leq 6.2$ \#\# & 24.3 & $24.3-21.1$ & 21.1-17.8 & $\leq 17.8$ \#\# \\
\hline \multicolumn{13}{|l|}{ Macronutrients } \\
\hline $\begin{array}{l}\text { Carbohydrates } \\
(\% \mathrm{E})\end{array}$ & 59.1 & 55-75 \#\#\# & 55-75 \#\#\# & 55-75 \#\#\# & 63.3 & 55-75 \#\#\# & 55-75 \#\#\# & 55-75 \#\#\# & 55.8 & 55-75 \#\#\# & 55-75 \#\#\# & 55-75 \#\#\# \\
\hline Free sugars (\%E) & 16.0 & $\leq 10 \# \# \#$ & $\leq 10 \# \# \#$ & $\leq 10 \# \#$ & 16.1 & $\leq 10 \# \# \#$ & $\leq 10 \# \# \#$ & $\leq 10 \# \# \#$ & 15.6 & $\leq 10 \# \# \#$ & $\leq 10 \# \# \#$ & $\leq 10 \# \# \#$ \\
\hline Protein (\%E) & 11.31 & 10-15 \#\#\# & 10-15 \#\#\# & 10-15 \#\#\# & 10.8 & 10-15 \#\#\# & 10-15 \#\#\# & 10-15 \#\#\# & 11.7 & 10-15 \#\#\# & 10-15 \#\#\# & 10-15 \#\#\# \\
\hline Total fat (\%E) & 29.6 & 15-30 \#\#\# & 15-30 \#\#\# & $15-30$ \#\#\# & 25.9 & $15-30$ \#\#\# & 15-30 \#\#\# & 15-30 \#\#\# & 32.5 & 15-30 \#\#\# & 15-30 \#\#\# & 15-30 \#\#\# \\
\hline $\begin{array}{l}\text { Saturated fat } \\
(\% \mathrm{E})\end{array}$ & 8.2 & $\leq 10 \# \# \#$ & $\leq 10 \# \# \#$ & $\leq 10 \# \# \#$ & 6.8 & $\leq 10 \# \#$ & $\leq 10 \# \#$ & $\leq 10 \# \#$ & 9.4 & $\leq 10 \# \# \#$ & $\leq 10 \# \#$ & $\leq 10 \# \#$ \\
\hline Total fiber (g) & 19.5 & $\geq 31 \S$ & $\geq 31 \S$ & $\geq 31 \S$ & 20.9 & $\geq 31 \S$ & $\geq 31 \S$ & $\geq 31 \S$ & 21.4 & $\geq 31 \S$ & $\geq 31 \S$ & $\geq 31 \S$ \\
\hline \multicolumn{13}{|l|}{ Micronutrients } \\
\hline Sodium (mg) & 3.951 .2 & $\leq 3.951$ & $\leq 3.951$ & $\leq 3.951$ & 4.434 .0 & $\leq 4.434$ & $\leq 4.434$ & $\leq 4.434$ & 3.699 .3 & $\leq 3.699$ & $\leq 3.699$ & $\leq 3.699$ \\
\hline Calcium (mg) & 314.0 & $\geq 315$ & $\geq 315$ & $\geq 315$ & 268.2 & $\geq 269$ & $\geq 269$ & $\geq 269$ & 380.6 & $\geq 381$ & $\geq 381$ & $\geq 381$ \\
\hline Iron (mg) & 11.7 & $\geq 10.7 \S \S$ & $\geq 10.7 \S \S$ & $\geq 10.7$ §§ & 11.4 & $\geq 10.7 \S \S$ & $\geq 10.7$ §§ & $\geq 10.7 \S \S$ & 13.4 & $\geq 10.7$ §§ & $\geq 10.7$ §§ & $\geq 10.7$ §§ \\
\hline Vitamin C (mg) & 28.5 & $\geq 29$ & $\geq 29$ & $\geq 29$ & 21.9 & $\geq 22$ & $\geq 22$ & $\geq 22$ & 38.6 & $\geq 39$ & $\geq 39$ & $\geq 39$ \\
\hline Vitamin A ( $\mu g)$ & $1,115.1$ & $\geq 803$ §§ & $\geq 803$ §§ & $\geq 803$ §§ & 967.5 & $\geq 803$ §§ & $\geq 803$ §§ & $\geq 803$ §§ & 1.434 .6 & $\geq 803$ §§ & $\geq 803$ §§ & $\geq 803 \S \S$ \\
\hline Potassium (mg) & $1,402.3$ & $\geq 1,403$ & $\geq 1,403$ & $\geq 1,403$ & $1,445.2$ & $\geq 1,446$ & $\geq 1,446$ & $\geq 1,446$ & $1,478.5$ & $\geq 1,479$ & $\geq 1,479$ & $\geq 1,479$ \\
\hline
\end{tabular}

* These diets explicit three gradual situations of approximation to the Brazilian dietary guidelines recommendations (increasing from 1 to 3 ). For further information, see the Methods section;

** Strata from the first tertile of per capita income distribution (BRL 389.80 per month; $n=262$ strata);

$* * *$ Strata from third tertile of per capita income distribution (BRL 1,570.60 per month; $n=146$ strata);

\# Average acquisition of the unprocessed or minimally processed food group in its fifth quintile of the relative contribution - largest acquisition;

\#\# Average acquisition of the ultra-processed food group in its first quintile of the relative contribution - lowest acquisition;

\#\#\# According to the World Health Organization 40;

$\S$ According to the U.S. Institute of Medicine 41;

$\S \S$ Derived from the estimated average requirement $41,42,43$. 
Table 2

Acceptability constraints on food content (Kcal/day), by income level (tertiles of per capita income distribution), imposed by the linear programming model. Brazil, 2008-2009.

\begin{tabular}{|c|c|c|c|c|c|c|}
\hline \multirow[t]{3}{*}{ Food groups and subgroups } & \multirow{2}{*}{\multicolumn{2}{|c|}{ Total }} & \multicolumn{4}{|c|}{ Tertiles of per capita income distribution } \\
\hline & & & \multicolumn{2}{|c|}{ 1st } & \multicolumn{2}{|c|}{3 rd } \\
\hline & $\begin{array}{c}\text { Lower } \\
\text { 10th } \\
\text { percentile }\end{array}$ & $\begin{array}{c}\text { Upper } \\
\text { 90th } \\
\text { percentile }\end{array}$ & $\begin{array}{c}\text { Lower } \\
\text { 10th } \\
\text { percentile }\end{array}$ & $\begin{array}{c}\text { Upper } \\
\text { 90th } \\
\text { percentile }\end{array}$ & $\begin{array}{c}\text { Lower } \\
\text { 10th } \\
\text { percentile }\end{array}$ & $\begin{array}{c}\text { Upper } \\
\text { 90th } \\
\text { percentile }\end{array}$ \\
\hline Unprocessed or minimally processed foods & 387.82 & 942.87 & 352.44 & 839.35 & 431.10 & 848.76 \\
\hline Rice & 36.85 & 203.76 & 38.83 & 215.84 & 32.55 & 151.38 \\
\hline Bean & 14.66 & 59.67 & 17.14 & 66.90 & 11.33 & 36.86 \\
\hline Pasta & 5.63 & 24.47 & 5.15 & 25.95 & 5.92 & 23.28 \\
\hline Wheat flour & 1.11 & 39.14 & 0.66 & 20.79 & 2.17 & 40.72 \\
\hline Cassava flour & 0.66 & 63.11 & 2.16 & 89.61 & 0.00 & 14.04 \\
\hline Fruits & 23.89 & 131.21 & 17.47 & 92.75 & 53.47 & 169.78 \\
\hline Vegetables & 22.69 & 92.48 & 15.71 & 62.63 & 41.98 & 105.13 \\
\hline Roots and tubers & 6.65 & 47.25 & 3.17 & 34.40 & 14.38 & 47.61 \\
\hline Milk and plain yoghurt & 25.04 & 237.62 & 16.01 & 167.50 & 74.75 & 255.38 \\
\hline Poultry and fish & 23.72 & 83.22 & 25.51 & 95.63 & 24.21 & 70.98 \\
\hline Beef and pork & 30.32 & 95.12 & 28.05 & 86.70 & 33.95 & 92.64 \\
\hline Eggs & 4.28 & 18.30 & 3.25 & 15.24 & 5.77 & 18.84 \\
\hline Other unprocessed or minimally processed foods * & 4.27 & 58.97 & 5.27 & 83.26 & 3.65 & 21.24 \\
\hline Processed culinary ingredients & 58.77 & 184.49 & 62.20 & 173.23 & 48.86 & 159.86 \\
\hline Sugar & 31.15 & 113.64 & 37.37 & 112.48 & 22.83 & 93.38 \\
\hline Salt & 2.94 & 21.60 & 3.77 & 21.82 & 2.09 & 18.63 \\
\hline Spice & 0.12 & 4.84 & 0.00 & 3.55 & 0.36 & 7.07 \\
\hline Plant oils & 11.20 & 43.58 & 10.51 & 40.68 & 10.06 & 43.77 \\
\hline Animal fats & 0.39 & 6.50 & 0.21 & 3.48 & 1.75 & 8.65 \\
\hline Other processed culinary ingredients ** & 0.33 & 13.40 & 0.43 & 16.46 & 0.36 & 10.08 \\
\hline Processed foods & 18.57 & 90.49 & 11.26 & 79.54 & 40.20 & 99.30 \\
\hline Fresh bread & 8.06 & 68.52 & 4.69 & 63.85 & 24.43 & 69.23 \\
\hline Processed cheeses & 0.58 & 14.56 & 0.00 & 8.01 & 4.81 & 20.99 \\
\hline Processed meats & 0.67 & 13.06 & 0.71 & 15.85 & 1.10 & 9.89 \\
\hline Processed vegetables & 0.55 & 6.96 & 0.27 & 3.89 & 1.97 & 10.01 \\
\hline Ultra-processed foods & 65.01 & 322.04 & 50.50 & 170.89 & 179.88 & 409.91 \\
\hline Industrial breads & 0.35 & 16.15 & 0.00 & 6.16 & 3.82 & 27.17 \\
\hline Cookies, cakes and pastries & 5.22 & 25.73 & 3.61 & 17.15 & 10.03 & 31.73 \\
\hline Ice creams, chocolates and other sweets & 1.65 & 23.57 & 0.86 & 8.11 & 8.88 & 34.09 \\
\hline Crackers and salty snacks & 2.44 & 14.04 & 2.64 & 15.98 & 3.00 & 13.04 \\
\hline Soft drinks & 22.95 & 147.78 & 12.69 & 80.36 & 56.56 & 183.30 \\
\hline Other non-alcoholic sweetened beverages & 2.64 & 37.92 & 1.33 & 15.72 & 14.25 & 69.86 \\
\hline Ultra-processed meats and sausages & 5.05 & 30.84 & 2.32 & 18.69 & 12.70 & 34.93 \\
\hline Ready meals and industrial blends & 2.56 & 30.25 & 1.11 & 15.27 & 10.36 & 40.19 \\
\hline Sauces and broths & 1.02 & 13.43 & 0.52 & 6.83 & 4.75 & 17.38 \\
\hline Breakfast cereals & 0.00 & 10.28 & 0.17 & 12.59 & 0.18 & 9.33 \\
\hline Margarine & 2.07 & 9.86 & 1.62 & 8.25 & 3.01 & 10.17 \\
\hline Ultra-processed cheeses & 0.00 & 2.01 & 0.00 & 0.70 & 0.32 & 3.56 \\
\hline
\end{tabular}

* Seafood; other cereals; other flours; legumes; nuts and seeds; normal or organic pure soy protein; dry/dehydrated fruits, legumes and vegetables;

** Other sugars; coconut milk. 


\section{Results}

About half (48.9\%) of the calories in the current diet were from unprocessed or minimally processed foods, $24.3 \%$ from processed culinary ingredients, $8.9 \%$ from processed foods and $17.8 \%$ from ultraprocessed foods. According to income distribution, the relative contribution of unprocessed or minimally processed foods and of processed culinary ingredients in the current diet was greater among low-income strata when compared with the high-income strata $(55.3 \%$, compared to $43.4 \%$ and $25.4 \%$, compared to $22.8 \%$, respectively), whereas the relative contribution of processed and ultraprocessed foods was greater in the high-income strata (9.5\%, compared to $7.5 \%$ and $24.3 \%$, compared to $11.8 \%$, respectively) (Table 3 ).

Three diets were optimized, presenting gradually increased contributions on their nutritional profile. Thus, the third optimized diet met even more the Brazilian dietary guidelines (Table 3 ). The relative contribution of unprocessed or minimally processed foods gradually increased in the optimized diets from $54.9 \%$ to $69.4 \%$ (compared to $48.9 \%$ from the current diet), the relative contribution of processed foods remained stable (8.9\%), whereas the relative contribution of processed culinary ingredients and ultra-processed foods decreased from $18.4 \%$ to $12.7 \%$ (compared to $24.3 \%$ from the current diet) and from $17.8 \%$ to $9.1 \%$ (compared to $17.8 \%$ from the current diet), respectively. A similar scenario was observed in the analysis according to income distribution (Table 3).

For the optimized diets, the nutritional constraints for macronutrients were adequately accepted in the linear programming model. However, it was not possible to find a feasible solution when the constraints for micronutrients were imposed on the linear programming model. The infeasible micronutrients were sodium, calcium, vitamin $\mathrm{C}$ and potassium. In this sense, a feasible solution was obtained after relaxing the constraints for these micronutrients in order to improve the nutritional profile of the optimized diets in relation to the current diet (Table 3).

The average cost of the current diet was BRL 3.37 per 2,000Kcal/person/day, ranging from BRL 1.90 for the purchase of unprocessed or minimally processed foods to BRL 0.20 for the purchase of processed culinary ingredients (Table 4). As optimized diets became healthier, their diet cost gradually decreased (from BRL 3.17 to BRL 2.91, compared to BRL 3.37 from the current diet). In the comparison, it represented a decrease of $13.65 \%$ (from BRL 3.37 to BRL 2.91) with the changes based on the Brazilian dietary guidelines towards a healthy eating (Table 4). According to income distribution, the current diet cost was lower among low-income strata (BRL 2.62) when compared with high-income strata (BRL 4.17) (Table 4). The cost of optimized diets decreased for both levels of income when comparison with current diet costs, representing a reduction of 5.34\% for low-income strata (from BRL 2.51 to BRL 2.48, compared to BRL 2.62 from the current diet) and of $8.15 \%$ for high-income strata (from BRL 4.06 to BRL 3.83, compared to BRL 4.17 from the current diet) (Table 4).

The commitment of food budget share from current diet was $11.38 \%$ for the total population, being greater among low-income strata (20.2\%) when compared with high-income ones $(7.96 \%)$ (Table 4). Food budget share decreased as the adoption of the Brazilian dietary guidelines were gradually increasing in the optimized diets, especially between the optimized diet 3 and the current diet: -1.55 percentage points (p.p.) for the total population (from $11.38 \%$ to $9.83 \%$, a reduction of $13.62 \%$ ), -1.10 p.p. for low-income strata (from $20.2 \%$ to $19.1 \%$, a reduction of $5.45 \%$ ) and -0.65 p.p. for highincome strata (from $7.96 \%$ to $7.31 \%$, a reduction of $8.17 \%$ ) (Table 4).

The relative contribution (\%) of food subgroups to total energy availability and its cost for the current diet and optimized diets are available on Table 5, both for the total population and for the income distribution. 
Table 3

Relative contribution (\%) of food groups to total energy availability, macro- and micronutrient for the current diet and optimized diets * by linear programming models, for the total population and for levels of income. Brazil, 2008-2009.

\begin{tabular}{|c|c|c|c|c|c|c|c|c|c|c|c|c|}
\hline \multirow[t]{4}{*}{ Variables } & \multicolumn{4}{|c|}{ Total } & \multicolumn{8}{|c|}{ Tertiles of per capita income distribution } \\
\hline & \multirow{3}{*}{$\begin{array}{c}\text { Current } \\
\text { diet }\end{array}$} & \multirow{2}{*}{\multicolumn{3}{|c|}{ Optimized diets }} & \multirow{3}{*}{$\begin{array}{c}\text { Current } \\
\text { diet }\end{array}$} & \multirow{2}{*}{\multicolumn{3}{|c|}{$\begin{array}{l}\text { 1st ** } \\
\text { Optimized diets }\end{array}$}} & \multirow{3}{*}{$\begin{array}{c}\text { Current } \\
\text { diet }\end{array}$} & \multirow{2}{*}{\multicolumn{3}{|c|}{$\begin{array}{l}\text { 3rd *** } \\
\text { Optimized diets }\end{array}$}} \\
\hline & & & & & & & & & & & & \\
\hline & & 1 & 2 & 3 & & 1 & 2 & 3 & & 1 & 2 & 3 \\
\hline \multicolumn{13}{|l|}{$\begin{array}{l}\text { Relative contribution (\%) } \\
\text { of food groups to total } \\
\text { energy availability }\end{array}$} \\
\hline $\begin{array}{l}\text { Unprocessed or } \\
\text { minimally processed } \\
\text { foods }\end{array}$ & 48.9 & 54.9 & 60.8 & $69.4 \#$ & 55.3 & 61.5 & 67.7 & $71.9 \#$ & 43.4 & 46.8 & 50.2 & $62.4 \#$ \\
\hline $\begin{array}{l}\text { Processed culinary } \\
\text { ingredients }\end{array}$ & 24.3 & 18.4 & 16.9 & 12.7 & 25.4 & 19.2 & 15.8 & 14.6 & 22.8 & 19.4 & 19.3 & 10.3 \\
\hline Processed foods & 8.9 & 8.9 & 8.9 & 8.9 & 7.5 & 7.5 & 7.5 & 7.3 & 9.5 & 9.5 & 9.5 & 9.5 \\
\hline Ultra-processed foods & 17.8 & 17.8 & 13.5 & $9.1 \# \#$ & 11.8 & 11.8 & 9.0 & $6.2 \# \#$ & 24.3 & 24.3 & 21.1 & $17.8 \# \#$ \\
\hline \multicolumn{13}{|l|}{ Macronutrients } \\
\hline Carbohydrates (\%E) & 59.1 & 64.3 \#\#\# & 67.1 \#\#\# & 72.2 \#\#\# & 63.3 & 66.4 \#\#\# & 70.5 \#\#\# & 71.9 \#\#\# & 55.8 & 59.4 \#\#\# & $61.3 \# \#$ & 69.6 \#\#\# \\
\hline Free sugars (\%E) & 16.0 & $9.5 \# \#$ & $8.4 \# \#$ & $7.8 \# \#$ & 16.1 & 10.0 \#\#\# & $9.6 \# \#$ & $9.0 \# \# \#$ & 15.6 & 10.0 \#\#\# & 10.0 \#\#\# & $7.9 \# \# \#$ \\
\hline Protein (\%E) & 11.3 & 10.9 \#\#\# & 10.8 \#\#\# & 10.7 \#\#\# & 10.8 & 10.6 \#\#\# & 10.8 \#\#\# & 10.9 \#\#\# & 11.7 & 11.1 \#\#\# & 11.2 \#\#\# & 11.3 \#\#\# \\
\hline Total fat (\%E) & 29.6 & 24.8 \#\#\# & 22.2 \#\#\# & 17.1 \#\#\# & 25.9 & 23.0 \#\#\# & 18.8 \#\#\# & 17.2 \#\#\# & 32.5 & 29.5 \#\#\# & 27.5 \#\#\# & 19.1 \#\#\# \\
\hline Saturated fat (\%E) & 8.2 & $6.6 \# \#$ & $6.0 \# \#$ & $5.0 \# \#$ & 6.8 & $5.9 \# \#$ & $5.2 \# \#$ & 4.9 \#\#\# & 9.4 & $8.2 \# \#$ & $7.7 \# \# \#$ & $6.1 \# \# \#$ \\
\hline Total fiber (g) & 19.5 & $31.0 \S$ & $31.0 \S$ & $31.0 \S$ & 20.9 & $31.0 \S$ & $31.2 \S$ & $31.2 \S$ & 21.4 & $31.0 \S$ & $31.0 \S$ & $31.0 \S$ \\
\hline \multicolumn{13}{|l|}{ Micronutrients } \\
\hline Sodium (mg) & $3,951.2$ & $3,951.0$ & $3,320.3$ & $3,449.2$ & $4,434.0$ & $3,364.0$ & $3,366.0$ & $3,717.4$ & $3,699.3$ & $3,699.0$ & $3,154.9$ & $2,910.5$ \\
\hline Calcium (mg) & 314.0 & 315.0 & 315.0 & 315.0 & 268.2 & 291.6 & 305.3 & 314.4 & 380.6 & 381.0 & 381.0 & 381.0 \\
\hline Iron (mg) & 11.7 & 16.5 §§ & $15.6 \S \S$ & $14.8 \S \S$ & 11.4 & $15.1 \S \S$ & $14.3 \S \S$ & $13.6 \S \S$ & 13.4 & $17.9 \S \S$ & 17.1 § & $16.4 \S$ \\
\hline Vitamin C (mg) & 28.5 & 41.4 & 43.6 & 44.6 & 21.9 & 32.0 & 33.6 & 33.9 & 38.6 & 54.9 & 55.7 & 56.7 \\
\hline Vitamin A ( $\mu g)$ & $1,115.1$ & $960.0 \S \S$ & $925.6 \S \S$ & 813.4 §§ & 967.5 & $861.5 \S \S$ & $904.4 \S \S$ & $913.6 \S \S$ & $1,434.6$ & $1,345.4 \S \S$ & $1,202.1 \S \S$ & 803.0 §§ \\
\hline Potassium (mg) & $1,402.3$ & 1.748 .1 & 1,797.9 & $1,848.9$ & $1,445.2$ & $1,819.2$ & $1,882.7$ & $1,941.5$ & $1,478.5$ & $1,715.5$ & $1,745.0$ & 1,798.0 \\
\hline
\end{tabular}

* These diets explicit three gradual situations of approximation to the Brazilian dietary guidelines recommendations (increasing from 1 to 3 ). For further information, see the Methods section;

** Strata from the first tertile of per capita income distribution (BRL 389.80 per month; $n=262$ strata);

*** Strata from third tertile of per capita income distribution (BRL 1,570.60 per month; $n=146$ strata);

\# Average acquisition of the unprocessed or minimally processed food group in its fifth quintile of the relative contribution - largest acquisition;

\#\# Average acquisition of the ultra-processed food group in its first quintile of the relative contribution - lowest acquisition;

\#\#\# According to the World Health Organization 40;

$\S$ According to the U.S. Institute of Medicine 41;

$\S \S$ Derived from the estimated average requirement $41,42,43$. 
Cost (BRL per 2,000Kcal/person/day) of food groups and commitment of income for the current diet and optimized diets * by linear programming models, for the total population and for levels of income. Brazil, 2008-2009.

\begin{tabular}{|c|c|c|c|c|c|c|c|c|c|c|c|c|c|c|c|}
\hline \multirow[t]{4}{*}{ Variáveis } & \multicolumn{5}{|c|}{ Total } & \multicolumn{10}{|c|}{ Tertiles of per capita income distribution } \\
\hline & \multirow{3}{*}{$\begin{array}{l}\text { Cur- } \\
\text { rent } \\
\text { diet }\end{array}$} & \multirow{2}{*}{\multicolumn{3}{|c|}{ Optimized diets }} & \multirow{3}{*}{$\begin{array}{c}\text { Delta } \\
\text { (3-cur- } \\
\text { rent } \\
\text { diet) }\end{array}$} & \multirow{3}{*}{$\begin{array}{l}\text { Cur- } \\
\text { rent } \\
\text { diet }\end{array}$} & \multicolumn{3}{|c|}{$1 \mathrm{st} * *$} & \multirow{3}{*}{$\begin{array}{c}\text { Delta } \\
\text { (3-cur- } \\
\text { rent } \\
\text { diet) }\end{array}$} & \multirow{3}{*}{$\begin{array}{l}\text { Cur- } \\
\text { rent } \\
\text { diet }\end{array}$} & \multicolumn{3}{|c|}{$3 r d * * *$} & \multirow{3}{*}{$\begin{array}{r}\text { Delta } \\
\text { (3-cur } \\
\text { rent } \\
\text { diet) }\end{array}$} \\
\hline & & & & & & & Opti & mized c & liets & & & Opti & mized & diets & \\
\hline & & 1 & 2 & 3 & & & 1 & 2 & 3 & & & 1 & 2 & 3 & \\
\hline \multicolumn{16}{|l|}{ Diet cost (BRL) } \\
\hline $\begin{array}{l}\text { Unprocessed } \\
\text { or minimally } \\
\text { processed foods }\end{array}$ & 1.90 & 1.81 & 1.94 & 2.07 & 0.17 & 1.71 & 1.68 & 1.78 & 1.85 & 0.14 & 2.09 & 2.07 & 2.17 & 2.34 & 0.25 \\
\hline $\begin{array}{l}\text { Processed } \\
\text { culinary } \\
\text { ingredients }\end{array}$ & 0.20 & 0.16 & 0.15 & 0.12 & -0.08 & 0.18 & 0.15 & 0.13 & 0.12 & -0.06 & 0.22 & 0.20 & 0.19 & 0.12 & -0.10 \\
\hline Processed foods & 0.36 & 0.34 & 0.34 & 0.35 & -0.01 & 0.26 & 0.25 & 0.26 & 0.26 & -0.01 & 0.45 & 0.43 & 0.44 & 0.41 & -0.04 \\
\hline $\begin{array}{l}\text { Ultra-processed } \\
\text { foods }\end{array}$ & 0.92 & 0.86 & 0.63 & 0.37 & -0.54 & 0.47 & 0.43 & 0.35 & 0.26 & -0.21 & 1.41 & 1.37 & 1.18 & 0.95 & -0.45 \\
\hline Total & 3.37 & 3.17 & 3.06 & 2.91 & -0.46 & 2.62 & 2.51 & 2.50 & 2.48 & -0.14 & 4.17 & 4.06 & 3.98 & 3.83 & -0.34 \\
\hline $\begin{array}{l}\text { Food budget share } \\
\text { (\%) }\end{array}$ & 11.38 & 10.72 & 10.33 & 9.83 & -1.55 & 20.20 & 19.33 & 19.28 & 19.10 & -1.10 & 7.96 & 7.76 & 7.61 & 7.31 & -0.65 \\
\hline
\end{tabular}

* These diets explicit three gradual situations of approximation to the Brazilian Dietary Guidelines (increasing from 1 to 3 ). For further information, see the Methods section;

** Strata from first tertile of per capita income distribution (BRL 389.8 per month; $\mathrm{n}=262$ strata);

$\star * \star$ Strata from third tertile of per capita income distribution (BRL 1,570.6 per month; $n=146$ strata).

\section{Discussion}

This is the first study to analyze the economic impact of the NOVA food classification system on Brazilian household budget. Based on the current population diet, three healthier diets were optimized by linear programming according to the Brazilian dietary guidelines, respecting nutritional constraints and acceptability. These optimized diets involved a gradual increase in the contribution of unprocessed or minimally processed foods, a reduction or stability of culinary ingredients and processed foods, and a gradual reduction of ultra-processed foods. The current diet cost (BRL 3.37 per 2,000 Kcal/person/day) was lower in low-income strata (BRL 2.62) than in high-income ones (BRL 4.17). Regardless of income distribution, diet cost and the food budget share decreased with the adoption of the Brazilian dietary guidelines.

The Brazilian dietary guidelines do not provide quantitative recommendations for food group consumption, but offer a more holistic approach to a healthier eating 20 . The greater advantage of this approach remains in the direct communication with the entire population, since no technical knowledge is necessary to apply the guidelines and benefit from it. As a result, individuals accessing the guidelines probably see this kind of recommendation as something closer to reality and thus, something feasible 21. Our study is based on the core guidelines on how to choose foods: "(i) make natural or minimally processed foods the basis of your diet (mainly of plant origin), (ii) use oils, fats, salt, and sugar in small amounts for seasoning and cooking foods, and to create culinary preparations, (iii) limit the use of processed foods, consuming them in small amounts as ingredients in culinary preparations or as part of meals, based on natural or minimally processed foods, and (iv) avoid ultra-processed foods" 6 (p. 11). 
Table 5

Relative contribution (\%) of food subgroups to total energy availability and its cost (BRL per 2,000Kcal/person/day) for the current diet and optimized diets *, estimated for the total population and for levels of income. Brazil, 2008-2009.

\begin{tabular}{|c|c|c|c|c|c|c|c|c|c|c|c|c|}
\hline \multirow{4}{*}{$\begin{array}{l}\text { Relative contribution (\%) of } \\
\text { food subgroups to total energy } \\
\text { availability }\end{array}$} & \multicolumn{4}{|c|}{ Total } & \multicolumn{8}{|c|}{ Tertiles of per capita income distribution } \\
\hline & \multirow{3}{*}{$\begin{array}{c}\text { Current } \\
\text { diet }\end{array}$} & & & & & & $1 s t$ ** & & & & $3 r d * * *$ & \\
\hline & & \multicolumn{3}{|c|}{ Optimized diets } & \multirow{2}{*}{$\begin{array}{c}\text { Current } \\
\text { diet }\end{array}$} & \multicolumn{3}{|c|}{ Optimized diets } & \multirow{2}{*}{$\begin{array}{l}\text { Current } \\
\text { diet }\end{array}$} & \multicolumn{3}{|c|}{ Optimized diets } \\
\hline & & 1 & 2 & 3 & & 1 & 2 & 3 & & 1 & 2 & 3 \\
\hline \multicolumn{13}{|l|}{$\begin{array}{l}\text { Unprocessed or minimally processed } \\
\text { foods }\end{array}$} \\
\hline Rice & 14.94 & 16.79 & 18.61 & 22.34 & 17.38 & 14.00 & 16.21 & 15.51 & 12.59 & 14.82 & 16.18 & 23.85 \\
\hline Bean & 5.30 & 10.19 & 10.16 & 10.19 & 7.09 & 11.33 & 11.35 & 11.40 & 3.83 & 6.29 & 6.29 & 6.29 \\
\hline Pasta & 2.41 & 2.17 & 2.38 & 2.75 & 2.51 & 2.43 & 2.67 & 3.00 & 2.39 & 2.23 & 2.31 & 3.88 \\
\hline Wheat flour & 2.14 & 1.85 & 1.98 & 2.25 & 1.28 & 1.17 & 1.29 & 1.44 & 2.55 & 2.35 & 2.38 & 3.99 \\
\hline Cassava flour & 2.93 & 4.02 & 5.46 & 7.29 & 6.16 & 10.78 & 12.62 & 14.92 & 0.80 & 0.79 & 0.87 & 1.56 \\
\hline Fruits & 2.49 & 4.16 & 4.28 & 4.36 & 2.00 & 3.35 & 3.49 & 3.50 & 3.17 & 5.17 & 5.25 & 5.25 \\
\hline Vegetables & 0.80 & 1.20 & 1.34 & 1.34 & 0.60 & 0.88 & 0.92 & 0.93 & 0.99 & 1.51 & 1.51 & 1.51 \\
\hline Roots and tubers & 1.10 & 1.21 & 1.40 & 1.72 & 0.83 & 0.87 & 0.97 & 1.09 & 1.25 & 1.30 & 1.59 & 1.88 \\
\hline Milk and plain yoghurt & 4.56 & 3.84 & 3.96 & 3.98 & 3.61 & 3.04 & 3.26 & 3.42 & 5.06 & 4.90 & 5.39 & 5.76 \\
\hline Poultry and fish & 4.21 & 2.18 & 2.13 & 2.12 & 5.03 & 3.31 & 3.28 & 3.36 & 3.50 & 2.07 & 2.07 & 2.07 \\
\hline Beef and pork & 5.07 & 2.68 & 2.69 & 2.68 & 4.73 & 3.18 & 3.17 & 3.27 & 5.10 & 2.99 & 2.99 & 2.99 \\
\hline Eggs & 0.71 & 0.55 & 0.54 & 0.58 & 0.66 & 0.57 & 0.62 & 0.69 & 0.73 & 0.57 & 0.53 & 0.40 \\
\hline $\begin{array}{l}\text { Other unprocessed or minimally } \\
\text { processed foods \# }\end{array}$ & 2.28 & 4.02 & 5.88 & 7.76 & 3.47 & 6.59 & 7.82 & 9.33 & 1.40 & 1.78 & 2.79 & 2.91 \\
\hline \multicolumn{13}{|l|}{ Processed culinary ingredients } \\
\hline Sugar & 11.61 & 6.21 & 6.21 & 6.21 & 13.54 & 7.58 & 7.64 & 7.77 & 9.40 & 5.26 & 6.29 & 4.55 \\
\hline Salt & 0.00 & 0.00 & 0.00 & 0.00 & 0.00 & 0.00 & 0.00 & 0.00 & 0.00 & 0.00 & 0.00 & 0.00 \\
\hline Spice & 0.04 & 0.03 & 0.03 & 0.04 & 0.02 & 0.02 & 0.02 & 0.03 & 0.05 & 0.05 & 0.05 & 0.06 \\
\hline Plant oils & 11.21 & 10.88 & 9.20 & 5.04 & 10.31 & 10.11 & 6.54 & 5.15 & 11.92 & 12.76 & 11.63 & 4.53 \\
\hline Animal fats & 0.77 & 0.63 & 0.65 & 0.58 & 0.47 & 0.42 & 0.46 & 0.48 & 0.91 & 0.83 & 0.77 & 0.52 \\
\hline $\begin{array}{l}\text { Other processed culinary } \\
\text { ingredients \#\# }\end{array}$ & 0.71 & 0.65 & 0.76 & 0.80 & 1.00 & 1.04 & 1.15 & 1.16 & 0.54 & 0.54 & 0.55 & 0.67 \\
\hline \multicolumn{13}{|l|}{ Processed foods } \\
\hline Fresh bread & 6.62 & 7.08 & 7.05 & 6.89 & 5.77 & 6.01 & 5.89 & 5.60 & 6.62 & 7.14 & 7.10 & 7.75 \\
\hline Processed cheeses & 1.03 & 0.78 & 0.76 & 0.79 & 0.47 & 0.41 & 0.45 & 0.49 & 1.66 & 1.28 & 1.15 & 0.72 \\
\hline Processed meats & 0.91 & 0.68 & 0.63 & 0.63 & 1.04 & 0.86 & 0.92 & 0.97 & 0.78 & 0.59 & 0.53 & 0.20 \\
\hline Processed vegetables & 0.32 & 0.34 & 0.44 & 0.57 & 0.22 & 0.21 & 0.24 & 0.27 & 0.42 & 0.47 & 0.70 & 0.81 \\
\hline
\end{tabular}

(continues)

However, transforming these recommendations in numeric parameters is a complex task that could be conducted in multiple ways. Since the Brazilian dietary guidelines has a qualitative proposal, international nutritional parameters were necessary to complement our analysis. In this sense, the main concern of our study was to provide alternatives that gradually reduce the gap between the current diet and the guidelines that are also feasible and acceptable by the population. The adoption of a plant-based diet could be difficult for many people, since it may require significant changes in food consumption and behavior 22. Analogous reasoning can also be applied to the considerable reduction or even removal of ultra-processed foods from the population diet. Thus, we chose to obtain the guiding parameters of the estimated diets direct from the Brazilian population, considering cultural and traditional factors, which could strongly affect food choices 23 . For such a purpose, the linear programming models were optimized to satisfy acceptability constraints, limited between the 10th and the 90th percentiles of the per capita energy distribution of each food in the total population 
Table 5 (continued)

\begin{tabular}{|c|c|c|c|c|c|c|c|c|c|c|c|c|}
\hline \multirow{4}{*}{$\begin{array}{l}\text { Relative contribution (\%) of } \\
\text { food subgroups to total energy } \\
\text { availability }\end{array}$} & \multirow{2}{*}{\multicolumn{4}{|c|}{ Total }} & \multicolumn{8}{|c|}{ Tertiles of per capita income distribution } \\
\hline & & & & & \multirow{3}{*}{$\begin{array}{l}\text { Current } \\
\text { diet }\end{array}$} & \multirow{2}{*}{\multicolumn{3}{|c|}{1 st ** }} & \multirow{3}{*}{$\begin{array}{l}\text { Current } \\
\text { diet }\end{array}$} & \multirow{2}{*}{\multicolumn{3}{|c|}{$\begin{array}{c}\text { 3rd *** } \\
\text { Optimized diets }\end{array}$}} \\
\hline & \multirow{2}{*}{$\begin{array}{l}\text { Current } \\
\text { diet }\end{array}$} & \multicolumn{3}{|c|}{ Optimized diets } & & & & & & & & \\
\hline & & 1 & 2 & 3 & & 1 & 2 & 3 & & 1 & 2 & 3 \\
\hline \multicolumn{13}{|l|}{ Ultra-processed foods } \\
\hline Industrial breads & 1.20 & 2.37 & 2.39 & 2.40 & 0.46 & 0.53 & 0.56 & 0.56 & 2.05 & 4.02 & 4.02 & 4.02 \\
\hline Cookies, cakes and pastries & 3.20 & 5.22 & 2.83 & 1.13 & 2.23 & 3.17 & 2.34 & 0.75 & 4.19 & 5.88 & 2.77 & 2.01 \\
\hline $\begin{array}{l}\text { Ice creams, chocolates and other } \\
\text { sweets }\end{array}$ & 2.07 & 0.74 & 0.29 & 0.29 & 0.82 & 0.63 & 0.54 & 0.32 & 3.46 & 1.54 & 1.54 & 1.54 \\
\hline Crackers and salty snacks & 1.58 & 2.59 & 2.84 & 2.87 & 1.88 & 3.51 & 2.42 & 2.15 & 1.43 & 2.00 & 2.52 & 2.88 \\
\hline Soft drinks & 1.63 & 0.42 & 0.43 & 0.42 & 0.88 & 0.53 & 0.39 & 0.29 & 2.23 & 1.01 & 1.01 & 1.01 \\
\hline $\begin{array}{l}\text { Other non-alcoholic sweetened } \\
\text { beverages }\end{array}$ & 0.53 & 0.38 & 0.26 & 0.07 & 0.23 & 0.20 & 0.20 & 0.20 & 0.88 & 0.72 & 0.37 & 0.37 \\
\hline $\begin{array}{l}\text { Ultra-processed meats and } \\
\text { sausages }\end{array}$ & 2.48 & 0.67 & 0.67 & 0.67 & 1.53 & 0.65 & 0.32 & 0.35 & 3.22 & 1.65 & 1.65 & 1.65 \\
\hline Ready meals and industrial blends & 2.18 & 3.89 & 2.41 & 0.34 & 1.06 & 1.08 & 1.00 & 0.69 & 3.46 & 5.33 & 5.33 & 3.13 \\
\hline Sauces and broths & 0.41 & 0.34 & 0.28 & 0.17 & 0.18 & 0.16 & 0.17 & 0.17 & 0.60 & 0.52 & 0.37 & 0.25 \\
\hline Breakfast cereals & 0.67 & 0.51 & 0.35 & 0.02 & 0.96 & 0.69 & 0.55 & 0.22 & 0.57 & 0.55 & 0.44 & 0.03 \\
\hline Margarine & 1.78 & 0.62 & 0.62 & 0.62 & 1.56 & 0.64 & 0.49 & 0.49 & 2.00 & 0.91 & 0.90 & 0.90 \\
\hline Ultra-processed cheeses & 0.12 & 0.09 & 0.09 & 0.09 & 0.03 & 0.03 & 0.03 & 0.03 & 0.22 & 0.18 & 0.14 & 0.04 \\
\hline
\end{tabular}

* Optimized diets by linear programming models. These diets explicit three gradual situations of approximation to the Brazilian dietary guidelines (increasing from 1 to 3 ). For further information, see the Methods section;

** Strata from first tertile of per capita income distribution (BRL 389.8 per month; $n=262$ strata);

*** Strata from third tertile of per capita income distribution (BRL 1,570.6 per month; $\mathrm{n}=146$ strata);

\# Seafood; other cereals; other flours; legumes; nuts and seeds; normal or organic pure soy protein; dry/dehydrated fruits, legumes and vegetables;

\#\# Other sugars; coconut milk.

and for levels of per capita income distribution (tertiles). Moreover, threshold levels of contribution of unprocessed or minimally processed foods and decrease of contribution of ultra-processed foods were based on levels of consumption for these groups have proven feasibility, considering that they are already adopted by about one out of five individuals in the country. It is worth mentioning that studies investigating effective food consumption data (based on $24 \mathrm{~h}$ dietary recall or food record) suggested that even more aggressive limits for the contribution of ultra-processed foods in the diet could be feasible (about $2 \%$ ) 24. However, we chose for the conservative approach, since we are modeling different kind of data (food purchases for household consumption for 7 days). Models with more aggressive threshold levels were estimated and reinforced our results (data not shown).

The impossibility to find a feasible solution when the constraints for micronutrients were imposed means that changes more aggressive than the one allowed here would be necessary to satisfy these constrains. However, when working with dietary guideline parameters estimated directly based on the Brazilian population, our results identified a feasible improvement in the nutritional profile. Besides, the international recommendations have been met to the maximum, since the Brazilian dietary guidelines do not provide quantitative recommendations for nutrients (macro or micro).

The relationship between diet cost and the adoption of healthy diets has been intensely studied worldwide 8,9. In a nationally representative sample of French adults (20-79 years), the diet cost increased for most individuals after reaching nutritional adequacy, and less adequate diets were associated with lower income individuals 9 . A representative sample of Japanese adults ( 20 or more years) also showed that the diet cost was inversely associated with dietary energy density. Lower diet cost was associated with a lower intake of vegetables, fruits, fish, meat and dairy products, and a higher intake of grain, eggs, fats and oils 8 . Unlike developed countries, where healthy diets are considerably more expensive than unhealthy diets, our results showed that Brazilian dietary guidelines could be 
adopted without compromising the total cost of the diet. Although this is the first study to analyze the economic impact on families related to the adoption of the most recent Brazilian dietary guidelines, evidence suggesting that Brazilian traditional diets based on rice and beans can help achieve these recommendations without increasing costs has already been available for a few years 10 . The data of our study complement this information, showing that the greater the consumption of unprocessed or minimally processed foods (with the exception of foods of animal origin) with the reduction of the consumption of ultra-processed foods, the lower the diet cost for the population and the better the nutritional composition of the diet.

The inverse relationship between income and food budget share is known for more than a century 25 and has been demonstrated in low, middle and high-income countries. Our results also reinforce this relationship, since the population in the first tertile of per capita income distribution compromises their budget more than two times the ones from the third tertile (20.2\%, compared to $7.96 \%$, respectively). This scenario favors the exposure of the lower income population to unhealthy eating practices that added to limited access to health services result in a disproportionate increase in the burden of obesity and associated NCD in this population 26,27. According to our study, incorporating the Brazilian dietary guidelines to current diet would benefit more low-income population strata (food budget share decreased 1.10p.p.) than high-income population strata (food budget share decreased 0.65p.p.). Thus, the viability of adopting the Brazilian dietary guideline emerges as an important tool for improving diet without increasing the cost and contributing to the reduction of these health inequities.

Although our results demonstrate the viability of Brazilian dietary guidelines, this is conditioned to other environmental factors such as availability, accessibility of retail food stores, the rapidity in the consumption of no-cook meals, the aggressive advertising and marketing of brands and others 28,29 . Changes in the price scenario presented in this work may also make the Brazilian dietary guidelines unfeasible. The WHO has encouraged action to change the food prices to improve population diet 3 . Three common pricing strategies may be adopted by the governments: (i) exemption of selected goods from a tax, (ii) taxes on specific foods, and (iii) subsidies or voucher systems targeted to high-risk groups 30,31 . Recently, the strategy most practiced has been the sugary drinks tax, since it is an easily defined category of products that are energy-dense and nutrient-poor, but with healthier substitutes 32,33 . However, Brazil is going the opposite way, often subsiding the production of ultra-processed foods with generous fiscal incentives 34,35. For instance, since 1990, tax exemptions have been granted by the Brazilian government to the big soda industry, totaling an exemption of about USD 2.0 billion of tax in little less than three decades 35,36 . Several bills aiming at correcting this scenario are currently under discussion on the Brazilian National Congress (such as Bill n. 8,541/2017 37), but with strong opposition from the big food and soda industries, which often finance groups of Federal Legislators 38 .

Some limitations of our study should be cited. First, although the Brazilian dietary guidelines do not provide quantitative recommendations for macro- and micronutrients, these international recommendations were used to guarantee the variety of foods in the optimized diets. According to Brazilian dietary guidelines, varieties within the same food group imply not only the diversity of flavors, aromas, colors and textures of the food and the supply of nutrients, but are also indispensable to accommodate regional and personal preferences 20. Second, only food and beverages purchased for household consumption were analyzed, since data of food consumption away from home was not available with sufficient information (most registers involved aggregated items - such as "fast food meal" or "breakfast buffet"- without specific details on weights or the specific foods). However, in 2008-2009, household food consumption responded by about 70\% of total food consumption 14 and about $84 \%$ of the calories consumed among Brazilians 39 . Therefore, such fraction has been enough to provide information with good validity. Last, income levels were defined according to per capita income levels. This approach has the advantage of its simplicity and widespread use in similar studies; however, it prevents considering differences in the demographic composition of the strata.

The results showed that Brazilian population could meet the Brazilian dietary guidelines with the improvement of their diet quality and a lower diet cost. Regardless of household income, the diet cost decreased with the adoption of the Brazilian dietary guideline. Although small changes in food prices do not tend to invalidate our conclusions, more acute variations (especially in relative prices) could. Thus, food price surveillance and policies capable to preserve economic advantage related to healthy 
eating practices are necessary to ensure the current viability of the Brazilian dietary guidelines for the coming years. Food price surveillance (of healthy and unhealthy foods) is required not only to guide future public actions, but also to indicate to the population more affordable ways to engage in healthy eating practices.

\section{Contributors}

E. G. Maia and R. M. Claro conceptualized the study, performed the statistical analysis, data interpretation, drafted and reviewed the manuscript. C. M. Passos, F. S. Granado and R. B. Levy participated in data interpretation and reviewed the manuscript critically for important intellectual content.

\section{Additional informations}

ORCID: Emanuella Gomes Maia (0000-0001-66550230); Camila Mendes dos Passos (0000-00031230-2500); Fernanda Serra Granado (0000-00025397-2685); Renata Bertazzi Levy (0000-00015388-7002); Rafael Moreira Claro (0000-00019690-575X).

\section{Acknowledgments}

This study was supported by Brazilian National Research Council (CNPq; grant numbers 309293/2016-2 and 407331/2016-6), Minas Gerais State Research Foundation (FAPEMIG; grant numbers APQ-02329-15 - 01/2015 and PPM-0032517 - 02/2017), the International Development Research Centre (IDRC; project ID - 108166) and the Brazilian Graduate Studies Coordinating Board (CAPES; finance code 001). The funding agencies had no role in the design, analysis or writing of this article.

\section{References}

1. World Health Organization. Noncommunicable diseases country profiles - 2018. Geneva: World Health Organization; 2019.

2. Institute for Health Metrics and Evaluation. GBD compare. https://vizhub.healthdata.org/ gbd-compare/ (accessed on 20/Jan/2019).

3. World Health Organization. Fiscal policies for diet and prevention of noncommunicable diseases. Geneva: World Health Organization; 2019.

4. Food and Agriculture Organization of the United Nations. Food-based dietary guidelines. http://www.fao.org/nutrition/educa tion/food-dietary-guidelines (accessed on 21/ Feb/2019).

5. Food and Agriculture Organization of the United Nations. Food-based dietary guidelines - Brazil. http://www.fao.org/nutrition/ education/food-based-dietary-guidelines/re gions/countries/brazil/en/ (accessed on 09/ Apr/2020).

6. Monteiro CA, Cannon G, Moubarac JC, Levy RB, Louzada MLC, Jaime PC. The UN decade of nutrition: the NOVA food classification and the trouble with ultra-processing. Public Health Nutr 2017; 21:5-17.

7. Glanz K, Sallis JF, Saelens BE, Frank LD. Healthy nutrition environments: concepts and measures. Am J Health Promot 2005; 19:330-3.

8. Okubo H, Murakami K, Sasaki S. Monetary value of self-reported diets and associations with sociodemographic characteristics and dietary intake among Japanese adults: analysis of nationally representative surveys. Public Health Nutr 2016; 19:3306-18. 
9. Maillot M, Vieux F, Delaere F, Lluch A, Darmon N. Dietary changes needed to reach nutritional adequacy without increasing diet cost according to income: an analysis among French adults. PLoS One 2017; 12:e0174679.

10. Claro RM, Maia EG, Costa BVL, Diniz DP. Preço dos alimentos no Brasil: prefira preparações culinárias a alimentos ultraprocessados. Cad Saúde Pública 2016; 32:e00104715.

11. Parlesak A, Tetens I, Dejgard J, Smed S, Gabrijelcic B, Rayner M, et al. Use of linear programming to develop cost-minimized nutritionally adequate health promoting food baskets. PLoS One 2016; 11:e0163411.

12. Akhter N, Saville N, Shrestha B, Manandhar DS, Osrin D, Costello A, et al. Change in cost and affordability of a typical and nutritionally adequate diet among socio-economic groups in rural Nepal after the 2008 food price crisis. Food Secur 2018; 10:615-29.

13. Nykänen E-PA, Dunning HE, Aryeetey RNO, Robertson A, Parlesak A. Nutritionally optimized, culturally acceptable, cost-minimized diets for low income Ghanaian families using linear programming. Nutrients 2018; 10:461.

14. Instituto Brasileiro de Geografia e Estatística. Pesquisa de Orçamentos Familiares 20082009: aquisição alimentar domiciliar per capita. Rio de Janeiro: Instituto Brasileiro de Geografia e Estatística; 2010.

15. Pereira RA, Souza AM, Duffey KJ, Sichieri R, Popkin BM. Beverages consumption in Brazil: results from the first National Dietary Survey. Public Health Nutr 2015; 18:1164-72.

16. Instituto Brasileiro de Geografia e Estatística. Estudo Nacional da Despesa Familiar: consumo alimentar e despesas das famílias. Rio de Janeiro: Instituto Brasileiro de Geografia e Estatística; 1978.

17. Núcleo de Estudos e Pesquisas em Alimentação, Universidade Estadual de Campinas. Tabela Brasileira de Composição de Alimentos (TACO). Campinas: Universidade Estadual de Campinas; 2011.

18. United States Department of Agriculture. USDA national nutrient database for standard reference. 23rd Ed. Washington DC: United States Department of Agriculture; 2010.

19. Darmon N, Ferguson EL, Briend A. A cost constraint alone has adverse effects on food selection and nutrient density: an analysis of human diets by linear programming. J Nutr 2002; 132:3764-71.

20. Departamento de Atenção Básica, Secretaria de Atenção à Saúde, Ministério da Saúde. Guia alimentar para a população brasileira. 2a Ed. Brasília: Ministério da Saúde; 2014.

21. Monteiro CA, Cannon G, Moubarac J-C, Martins APB, Martins CA, Garzillo J, et al. Dietary guidelines to nourish humanity and the planet in the twenty-first century. A blueprint from Brazil. Public Health Nutr 2015; 18:2311-22.

22. van Dooren C, Marinussen M, Blonk H, Aiking $\mathrm{H}$, Vellinga P. Exploring dietary guidelines based on ecological and nutritional values: a comparison of six dietary patterns. Food Policy 2014 ; 44:36-46.
23. Maillot M, Darmon N, Drewnowski A. Are the lowest-cost healthful food plans culturally and socially acceptable? Public Health Nutr 2010; 13:1178-85.

24. Louzada MLC, Martins APB, Canella DS, Baraldi LG, Levy RB, Claro RM, et al. Ultraprocessed foods and the nutritional dietary profile in Brazil. Rev Saúde Pública 2015; 49:38.

25. Houthakker HS. An international comparison of household expenditure patterns, commemorating the centenary of Engel's Law. Econometrica 1957; 25:532-51.

26. Allen L, Williams J, Townsend N, Mikkelsen B, Roberts N, Foster C, et al. Socioeconomic status and non-communicable disease behavioural risk factors in low-income and lowermiddle-income countries: a systematic review. Lancet Glob Health 2017; 5:e277-89.

27. World Health Organization. Noncommunicable diseases. http://www.who.int/media centre/factsheets/fs355/en/ (accessed on 12/ Nov/2019).

28. Duran AC, Almeida SL, Latorre MR, Jaime PC. The role of the local retail food environment in fruit, vegetable and sugar-sweetened beverage consumption in Brazil. Public Health Nutr 2016; 19:1093-102.

29. Black C, Moon G, Baird J. Dietary inequalities: what is the evidence for the effect of the neighbourhood food environment? Health Place 2014; 27:229-42.

30. Lee A, Mhurchu CN, Sacks G, Swinburn B, Snowdon W, Vandevijvere S. Monitoring the price and affordability of foods and diets globally. Obes Rev 2013; 14:82-95.

31. Niebylski ML, Redburn KA, Duhaney T, Campbell NR. Healthy food subsidies and unhealthy food taxation: a systematic review of the evidence. Nutrition 2015; 31:787-95.

32. World Health Organization. Taxes on sugary drinks: why do it? Geneva: World Health Organization; 2017.

33. Nakamura R, Mirelman AJ, Cuadrado C, SilvaIllanes N, Dunstan J, Suhrcke M, et al. Evaluating the 2014 sugar-sweetened beverage tax in Chile: an observational study in urban areas. PLoS Med 2018; 15:e1002596.

34. Associação dos Fabricantes de Refrigerantes do Brasil. Por trás do rótulo: créditos de IPI quebram o setor de bebidas. https://afre bras.org.br/conteudos/ (accessed on 15/ Mar/2019).

35. Zocchio J. Após taxação, pesquisa mostra queda no consumo de bebidas adoçadas no México. O Joio e o Trigo 2019; 15 jan. https:// ojoioeotrigo.com.br/2019/01/apos-taxacaopesquisa-mostra-queda-no-consumo-de-bebi das-adocadas-no-mexico/.

36. Peres J. Toma essa: os bilhões que damos todos os anos à indústria de refrigerantes. O Joio e o Trigo 2017; 30 oct. https://ojoioeotrigo.com. $\mathrm{br} / 2017 / 10 /$ toma-essa-os-bilhoes-que-da mos-todos-os-anos-industria-de-refrigeran tes/. 
37. Teixeira P. Projeto de Lei no 8.541/2017. Aumento da tributação para bebidas açucaradas não é consenso em comissão. https://www.ca mara.leg.br/proposicoesWeb/fichadetramita cao?idProposicao=2150996 (accessed on 15/ Mar/2019).

38. Peres J. Presidente do PSDB usou o cargo para tratar de atividade como investidor da Coca. O Joio e o Trigo 2017; 27 oct. https://ojoioe otrigo.com.br/2017/10/presidente-do-psdbusou-o-cargo-para-tratar-de-atividade-comoinvestidor-da-coca/.

39. Instituto Brasileiro de Geografia e Estatística. Pesquisa de Orçamentos Familiares 20082009: análise do consumo alimentar pessoal no Brasil. Rio de Janeiro: Instituto Brasileiro de Geografia e Estatística; 2011.
40. World Health Organization. Diet, nutrition and the prevention of chronic diseases. Geneva: World Health Organization; 2003. (WHO Technical Report Series, 916).

41. Institute of Medicine. Dietary reference intakes: the essential guide to nutrient requirements. Washington DC: Institute of Medicine; 2006.

42. Institute of Medicine. Dietary reference intakes for vitamin C, vitamin E, selenium, and carotenoids. Washington DC: Institute of Medicine; 2000.

43. Institute of Medicine. Dietary reference intakes for calcium and vitamin D. Washington DC: Institute of Medicine; 2011. 


\section{Resumo}

O objetivo desse estudo foi analisar o impacto econômico da adoção de dietas otimizadas e nutricionalmente balanceadas para famílias brasileiras, considerando as diretrizes alimentares para a população brasileira e as disparidades econômicas da população. Foram usados dados da Pesquisa de Orçamentos Familiares de 2008-2009 (550 estratos; 55.970 domicílios). Cerca de 1,7 mil alimentos e bebidas adquiridos pelos brasileiros foram classificados em quatro grupos de acordo com o sistema NOVA. Modelos de programação linear estimaram dietas isoenergéticas preservando a dieta atual como linha de base e otimizando dietas mais saudáveis gradativamente com base na "regra de ouro" das diretrizes alimentares, respeitando restrições nutricionais para macronutrientes e micronutrientes (com base em recomendações internacionais) e limites de aceitação alimentar (10o e 90 o percentis da distribuição de calorias per capita da população). O custo da dieta foi definido a partir da soma do custo médio de cada grupo de alimentos, tanto na dieta atual quanto na otimizada (R\$ por $2.000 \mathrm{Kcal} /$ pessoa/dia). O impacto econômico das diretrizes alimentares para o orçamento familiar brasileiro foi analisado comparando-se o custo das dietas otimizadas com o custo da dieta atual, calculado para a população total e por nível de renda. Três dietas mais saudáveis foram otimizadas. $O$ custo da dieta atual era de $R \$ 3,37$, diferindo entre os estratos de baixa e alta renda ( $R \$$ $2,62$ vs. $R \$ 4,17)$. Independentemente da renda, o custo da dieta diminuiu com a abordagem das diretrizes. No entanto, os estratos de baixa renda comprometeram seu orçamento familiar mais de duas vezes que os estratos de alta renda (20,2\% vs. 7,96\%). Assim, a adoção de práticas alimentares mais saudáveis pode ser realizada com orçamento igual ou inferior.

Ingestão de Alimentos; Custos e Análise e Custo; Programação Linear

\section{Resumen}

El objetivo del estudio fue analizar el impacto económico de la adopción de dietas optimizadas y nutricionalmente equilibradas en familias brasileñas, considerando las guías alimentarias y las disparidades económicas de la población. Los datos se recopilaron de la Encuesta de Presupuestos por Hogares desde 2008-2009 (550 estratos; 55 970 hogares). Se clasificaron alrededor de 1.700 comidas y bebidas, adquiridas por brasileños en 4 grupos, según el sistema NOVA. Los modelos de programación lineal estimaron dietas isoenergéticas, preservando la dieta actual como base de referencia, y optimizando las dietas más sanas gradualmente, basadas en la "regla de oro" de las guías alimentarias, respecto a restricciones $n u$ tricionales en macronutrientes y micronutrientes (basadas en recomendaciones internacionales), $y$ los límites de aceptación alimentarios (10o y 90 o percentiles de la distribución calórica per cápita de la población). El coste de la dieta se definió basado en el total del coste medio de cada grupo de comida, ambos en las dietas actual y optimizada (BRL por 2.000Kcal/persona/día). El impacto económico de las guías alimentarias para el presupuesto por hogar se analizó mediante comparación del coste de dietas optimizadas con el coste de la dieta actual, calculado para el total de población y por nivel de ingresos. Se optimizaron las tres dietas más saludables. El coste de la dieta actual fue BRL 3,37 , diferenciando los estratos entre bajo- $y$ altosingresos (BRL 2, 62 y BRL 4,17, respectivamente). A pesar del ingreso, el coste de la dieta decreció cuando se aproximaba a las recomendaciones de las guías. No obstante, los estratos de bajos ingresos comprometieron su presupuesto doméstico más de dos veces, respecto a los estratos de ingresos más altos (20,2\% y 7,96\%, respectivamente). Por ello, la adopción de prácticas alimentarias más sanas se puede conseguir con el mismo presupuesto o incluso más bajo.

Ingestión de Alimentos; Costos y Análisis de Costo; Programación Lineal
Submitted on 02/May/2020

Final version resubmitted on 18/Jan/2021

Approved on 01/Feb/2021 